\title{
Sequential pathology of experimental pasteurellosis in gilthead seabream Sparus aurata. A light- and electron-microscopic study
}

\author{
M. Noya ${ }^{1}$, B. Magariños ${ }^{2}$, A. E. Toranzo ${ }^{2}$, J. Lamas $^{1}$

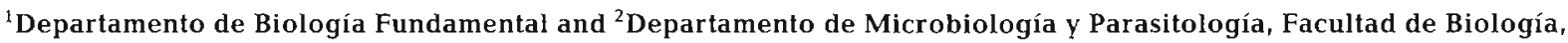 \\ Universidad de Santiago de Compostela, E-15706 Santiago de Compostela, Spain
}

\begin{abstract}
The haematological and histopathological changes caused by Pasteurella piscicida or by its extracellular products (ECPs) are described for gilthead seabream Sparus aurata following experimental infection. Results indicate that the ECPs were haemolytic in vivo, causing a significant decrease in the number of circulating red blood cells. However, this decrease was not significant in fish injected with bacteria. The inflammatory response induced by bacteria and ECPs was similar, including lymphopenia, granulocytosis, an increase in the number of peritoneal exudate cells, and mobilization and degranulation of the eosinophilic granular cells. The study of peritoneal exudate cells showed that at 1 and 6 h post-injection numerous peritoneal granulocytes had engulfed 1 or 2 bacteria per cell. Granule discharge occurred, and altered bacteria were frequently observed in the phagocytic vacuoles of these granulocytes. Macrophages containing phagocytosed bacteria were also noted. After $1 \mathrm{~d}, P$. piscicida occurred in large numbers within the peritoneal macrophages. These bacteria were apparently intact. The histopathological study showed that the bacterium was mainly phagocytosed by macrophages and that the latter accumulated in several organs. Macrophages with engulfed bacteria appeared in the kidney and spleen at 6 h post-injection. After $2 d$, high numbers of macrophages, singly or in aggregates, containing abundant phagocytosed bacteria, were observed in these organs. In later stages of the infection, the occurrence of degenerate macrophages full of intact-appearing bacteria and of bacterial colonies of different sizes suggested that macrophages played an important role in disseminating the pathogen throughout the fish. The lesions observed in the muscle adjacent to the site of injection and in the spleen ellipsoids of fish injected with ECPs were rare, possibly due to the low proteolytic activity of ECPs. In contrast, fish injected with ECPs developed severe lesions in the liver and gills, suggesting the presence of toxin(s) which may be important in the pathogenesis of pasteurellosis
\end{abstract}

KEY WORDS: Gilthead seabream - Pasteurella piscicida $\cdot$ Live cells $\cdot$ Extracellular products - Haematology $\cdot$ Histopathology

\section{INTRODUCTION}

The importance of Pasteurella piscicida as a pathogen responsible for extensive losses in different species of wild and farmed marine fish has been reported in numerous studies (see reviews of Toranzo et al. 1991, Kitao 1993, Kusuda \& Salati 1993, Thune et al. 1993). External pathological signs of pasteurellosis are usually inconspicuous, surface lesions usually being absent in affected fish. Internally, infected fish show septicaemia and necrosis in most organs and can develop whitish areas in the spleen and kidney (Kubota et al. 1970a, Wolke 1975, Tung et al. 1985, Hawke et al. 1987, Toranzo et al. 1991).

It has been reported that the extracellular products (ECPs) of Pasteurella piscicida are strongly toxic for fish when injected intraperitoneally. In addition, these ECPs display in vitro haemolytic activity in turbot Scophthalmus maximus and rainbow trout Oncorhynchus mykiss and also contain a high phospholipase activity (Magariños et al. 1992). These studies suggest that the ECPs are involved in the pathogenesis of $P$. 
piscicida, although their contribution to the pathology of pasteurellosis is still unknown.

In this study we compared the lesions caused by Pasteurella piscicida and by its ECPs in juvenile gilthead seabream Sparus aurata. The results indicated that $P$. piscicida ECPs were haemolytic and caused severe morphological changes in some of the organs analysed when injected. In consequence, the toxins included in the ECPs may be important factors in the pathogenesis of the disease.

\section{MATERIALS AND METHODS}

Bacteria and extracellular products (ECPs). A virulent strain of Pasteurella piscicida (DI-21), originally isolated from seabream, was used in this study. The lethal dose $\left(\mathrm{LD}_{50}\right)$ of the strain for this fish species was $1.6 \times 10^{5}$ cells fish $^{-1}$ (Toranzo et al. 1991, Magariños et al. 1992). Cultures were stored frozen at $-70^{\circ} \mathrm{C}$ in Tryptic Soy Broth (TSB, Difco) with 15\% (v/v) glycerol until use. For these experiments, bacteria were grown overnight at $22^{\circ} \mathrm{C}$ in Brain-Heart Infusion broth (Difco) supplemented with $\mathrm{NaCl}$ to a final concentration of $2 \%$ (BHI-2). The bacterial suspension was centrifuged at $6000 \times g$ for $30 \mathrm{~min}$ and resuspended in sterile phosphate-buffered saline (PBS) to obtain an initial concentration of approximately $10^{9}$ cells $\mathrm{ml}^{-1}$ (MacFarland standard no. 3). For injection into the fish, serial 10 -fold dilutions of the bacterial suspensions were made in the same buffer.

ECPs were prepared by the cellophane overlay method as described by Magariños et al. (1992). Sterilised cellophane sheets were placed on the surface of Brain-Heart Infusion Agar plates containing a final concentration of $2 \% \mathrm{NaCl}$ (BHIA-2). The sheets were inoculated with $0.5 \mathrm{ml}$ of bacterial suspension and incubated for $48 \mathrm{~h}$ at $22^{\circ} \mathrm{C}$. The bacterial cells were scraped from the sheets with PBS and centrifuged at $10000 \times g$ at $4^{\circ} \mathrm{C}$ for $30 \mathrm{~min}$. The supernatant was then filtered through $0.45 \mu \mathrm{m}$ (Millipore) filter and lyophilised. Before inoculation, the ECPs were redissolved in sterile PBS and the protein concentration determined by the method of Bradford (1976). The ECPs used in this study had a haemolytic activity for seabream erythrocytes of $150 \mathrm{U} \mathrm{ml}^{-1}$, a proteolytic activity of $0.5 \mathrm{U} \mathrm{ml}^{-1}$, and a phospholipase activity of $400 \mathrm{U} \mathrm{ml}^{-1}$ at a concentration of $2.8 \mathrm{mg}$ protein $\mathrm{ml}^{-1}$.

Fish. Juvenile gilthead seabream Sparus aurata weighing approximately 5 to $10 \mathrm{~g}$ were used. Fish were maintained in aerated recirculating seawater at $18^{\circ} \mathrm{C}$ during the course of the experiment $(2 \mathrm{wk})$.

Bacteria and ECP injection. Groups of 30 fish were injected intraperitoneally with $0.1 \mathrm{ml}$ of Pasteurella piscicida strain DI-21 $\left(10^{5}\right.$ to $10^{6}$ cells $\mathrm{ml}^{-1}$ of $\left.\mathrm{PBS}\right)$ or with $0.1 \mathrm{ml}$ of different concentrations of ECPs $(2.8$, 0.70 , and $0.28 \mathrm{mg}$ protein $\mathrm{ml}^{-1}$ of PBS) derived from the same strain. The lethal dose $\left(\mathrm{LD}_{50}=2.8 \mu \mathrm{g}\right.$ protein $\mathrm{g}^{-1}$ fish) of the ECPs was previously determined following procedures described by Magariños et al. (1992). Controls were injected with $0.1 \mathrm{ml}$ of PBS. At least 2 fish of each group were randomly sampled at 1 and $6 \mathrm{~h}$, and at $1,2,3,4$ and $5 \mathrm{~d}$ after injection. In addition, the remaining fish were collected when they became moribund (i.e. those showing changes in colour, irregular swimming, and loss of equilibrium).

Blood and peritoneal exudate cells. Blood and peritoneal exudate cells were obtained from controls and fish injected with bacteria or ECPs. Following anaesthesia with 3 -aminobenzoic acid ethyl ester (Sigma), blood was collected from the caudal vessel in a heparinized tube. Peritoneal exudate cells were obtained from the abdominal cavity after a careful wash with saline. Blood and peritoneal exudate cells were counted microscopically with an haemocytometer.

Blood and intraperitoneal liquid smears were fixed in methanol and stained with May-Grünwald-Giemsa (M-G), peroxidase, and periodic acid-Schiff (PAS) methods. PAS smears were counterstained with haematoxylin. One hundred cells were examined microscopically in each smear and the percentage of granulocytes, lymphocytes, thrombocytes and monocytes determined

Although counts were carried out in all fish, only the blood and peritoneal exudate cell counts of 10 fish injected with ECP $\left(0.28 \mathrm{mg}\right.$ protein $\left.\mathrm{ml}^{-1}\right)$ and 10 fish injected with bacteria, which became moribund between 3 and 4 d post-injection, were compared statistically.

Presentation of quantitative data. Quantitative results were subjected to an analysis of variance (ANOVA) and are shown as the mean \pm the standard deviation. A significance level of $\alpha=0.05$ was used.

Light and electron microscopy. Tissue samples (gill intestine, heart, Iiver, kidney and spleen) from injected and control fish were fixed with Bouin's and processed for light microscopy. Sections $7 \mu \mathrm{m}$ thick were stained with haematoxylin-eosin. Other tissue samples were fixed for $6 \mathrm{~h}$ with $2 \%$ glutaraldehyde and $1 \%$ formaldehyde in $0.067 \mathrm{M}$ Sörensen buffer ( $\mathrm{pH} 7.4$ ) and then post-fixed for $2 \mathrm{~h}$ with $1 \% \mathrm{OsO}_{4}$ in the same buffer. After dehydration in a graded acetone series, the tissues were embedded in Spurr resin. Semithin sections (1 $\mu \mathrm{m}$ thick) were cut on a Reichert-Jung ultramicrotome and stained with $1 \%$ toluidine blue solution. For transmission electron microscopy (TEM), ultrathin sections were double-stained with uranyl acetate and lead citrate and examined with a Philips CM 12 microscope. 
Table 1. Sparus aurata. Changes in blood and peritoneal exudate cells, in gilthead seabream injected intraperitoneally with Pasteurella piscicida or with extracellular products (ECPs). The fish serving as source of the samples had become moribund between 3 and $4 \mathrm{~d}$ post-injection. Results are expressed as the mean value for 10 fish. Significantly different from control values

\begin{tabular}{|c|c|c|c|}
\hline Parameters & Controls & Bacteria & ECPs \\
\hline Red blood cell counts $\left(\times 10^{6} \mu \mathrm{l}^{-1}\right)$ & $1.7 \pm 0.12$ & $1.5 \pm 0.26$ & $1.4 \pm 0.06^{\circ}$ \\
\hline White blood cell counts $\left(\times 10^{3} \mu \mathrm{l}^{-1}\right)$ & $31.6 \pm 14.8$ & $46.8 \pm 6.1^{\circ}$ & $53.4 \pm 13.9^{\circ}$ \\
\hline \multicolumn{4}{|l|}{ Differential cell counts from blood smears } \\
\hline Lymphocytes $(\%)$ & $73.6 \pm 9.5$ & $47.2 \pm 15.3^{\circ}$ & $20.8 \pm 6.04^{\circ}$ \\
\hline Granulocytes $(\%)$ & $12 \pm 7.6$ & $16.8 \pm 9.2$ & $40.8 \pm 22.4^{\circ}$ \\
\hline Thrombocytes $(\%)$ & $14 \pm 7.8$ & $36 \pm 16^{\circ}$ & $37.8 \pm 20.3^{\circ}$ \\
\hline Peritoneal exudate cell counts $\left(\times 10^{3} \mathrm{ml}^{-1}\right)$ & $287.5 \pm 130.4$ & $937.5 \pm 412.7^{\circ}$ & $1217.5 \pm 341.7^{\circ}$ \\
\hline
\end{tabular}

\section{RESULTS}

The majority of fish inoculated with the ECPs containing the highest dose of protein became moribund in less than $24 \mathrm{~h}$. Fish injected with the lowest dose reached this state between Days 2 and 3. In comparison, fish injected with bacteria became moribund between Days 3 and 5.

\section{Gross lesions}

Both groups of fish injected with bacteria or ECPs showed darkening of the dorsal and lateral surface of the body when they became moribund, but no other external changes were observed in most fish. Fish showed abundant accumulation of ascitic fluid although haemorrhages in internal organs were not observed. Some fish injected with ECPs showed exophthalmia.

\section{Haematological changes}

The number of erythrocytes decreased significantly in fish injected with ECPs (Table 1). Although some fish injected with bacteria showed low erythrocyte numbers, mean erythrocyte numbers in challenged and control fish were not significantly different.

The number of leucocytes and granulocytes increased in both fish injected with bacteria and with ECPs. However, in both groups, the number of lymphocytes decreased significantly (Table 1). Monocytes, scarce in the blood of control fish, were frequently observed in the blood of injected fish.

Fish injected with bacteria or with ECPs also showed degenerated erythrocytes and leucocytes as well as abundant circulating erythroblasts and immature granulocytes. Granulocytes of these fish showed a marked increase in the PAS positivity. In fish in- jected with bacteria, degenerate granulocytes usually showed phagocytosed bacteria. Monocytes with phagocytosed bacteria were also noted. Septicaemia was only observed, however, in 8 of 28 (28\%) moribund fish which were injected with bacteria.

\section{Changes in the peritoneal exudate cells}

Regardless of the injected inoculum (bacteria or ECPs), a marked increase in the number of exudate cells was observed in the peritoneal fluid $3 \mathrm{~d}$ after injection (Table 1). These cells were mainly granulocytes, macrophages and eosinophilic granular cells.

Examination of peritoneal exudate cells $1 \mathrm{~h}$ after injection of bacteria showed that many of the granulocytes contained 1 or 2 phagocytosed bacteria per cell. Bacteria were also occasionally observed in macrophages. Study of the peritoneal exudate cells with TEM showed that granulocytes suffered an intense degranulation during which the granule contents were released into the phagosomes which contained bacteria in process of being degraded (Fig. 1). At $6 \mathrm{~h}$ after injection, numerous granulocytes appeared necrotic, some of them containing degraded bacteria. At this stage, peritoneal macrophages containing moderate amounts of phagocytosed bacteria and cell debris, probably mainly degenerated granulocytes, were observed. These phagocytosed bacteria were normal in appearance. From 1 to $5 \mathrm{~d}$ post-injection, large numbers of phagocytosed bacteria occurred in peritoneal macrophages (Fig. 2a). These bacteria did not suffer any apparent morphological changes. However, some of the macrophages showed a necrotic appearance. At this stage, occasional granulocytes containing phagocytosed bacteria were also observed (Fig. 2b).

At $1 \mathrm{~h}$ after injection, fish injected with ECPs had numerous degenerate cells, mainly granulocytes, in the peritoneal exudate. With time, macrophages con- 

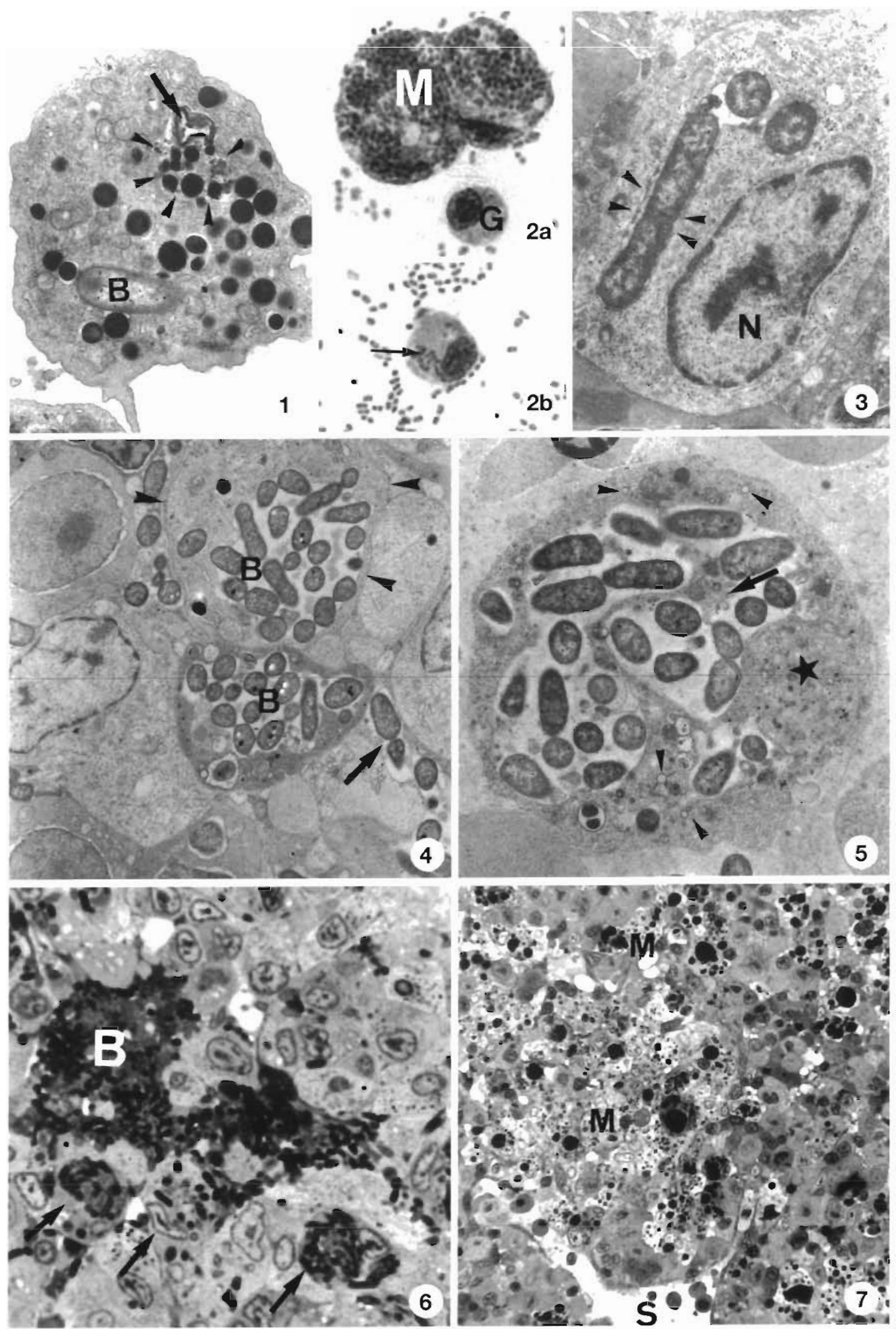

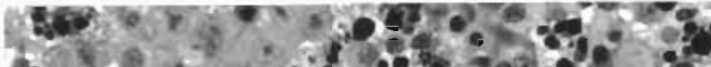

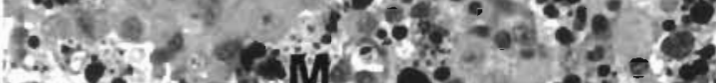

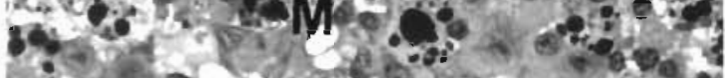

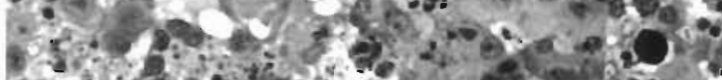

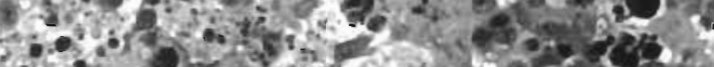

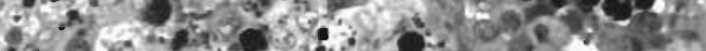

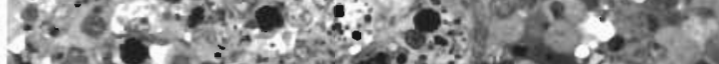

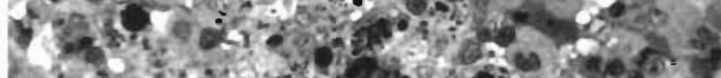
Lis.

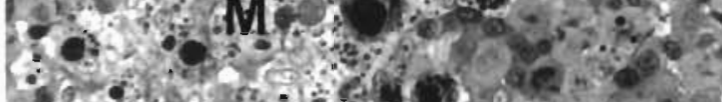

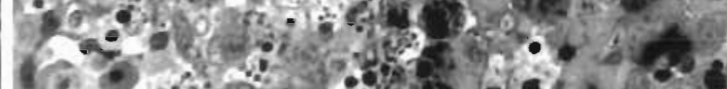

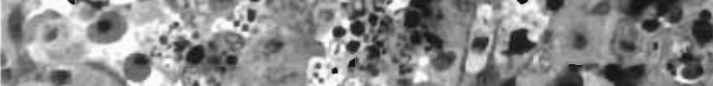

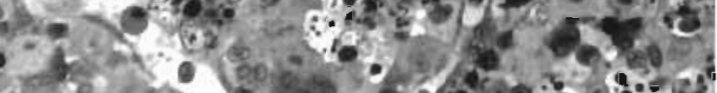

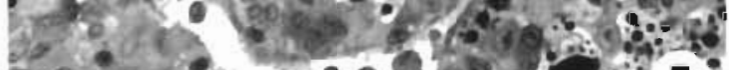

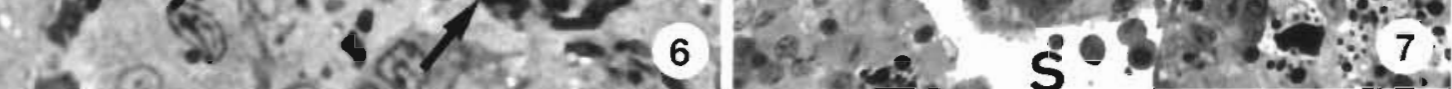


taining large amounts phagocytosed cell debris were observed. These macrophages were especially abundant at $6 \mathrm{~h}$ and $1 \mathrm{~d}$ after intraperitoneal injection.

\section{Histopathology}

Fish that became moribund in the first 6 h after injection of ECPs had few, if any, histopathological changes in the organs studied. After $1 \mathrm{~d}$, alterations became more evident, and after $3 \mathrm{~d}$ they were especially severe.

\section{Kidney and spleen}

At $6 \mathrm{~h}$ after bacterial injection, scattered macrophages containing a few phagocytosed bacteria were observed in the kidney and spleen. These phagocytosed bacteria were normal in appearance (Fig. 3). After $2 \mathrm{~d}$, the kidney showed a high number of macrophages which accumulated in sinusoids and, occasionally, in the haematopoietic tissue. In the spleen, macrophages accumulated in the red pulp, the periellipsoidal areas, or adjacent to the capillary walls. The melanomacrophage centres, little developed in control fish, increased markedly in size. Although in the first stages of infection macrophages contained low numbers of phagocytosed bacteria, with time, large numbers of macrophages full of bacteria appeared and accumulated in aggregates. These phagocytosed bacteria were apparently unaffected (Fig. 4). Necrotic macrophages full of phagocytosed bacteria (Fig. 5) and large bacterial colonies (Fig. 6) were also observed.

Fish injected with ECPs showed an increase in the number of macrophages $24 \mathrm{~h}$ post-injection. After $3 \mathrm{~d}$, large numbers of hypertrophied macrophages occurred in the kidney and the spleen. The macrophages contained mainly degenerate erythrocytes and cell debris. In the kidney, macrophages occupied the sinu- soids and most of interstitial haematopoietic tissue (Fig. 7). In the spleen, macrophages (Fig. 8) were located in the ellipsoidal or in the capillary walls and in the red pulp. The endothelial cells of the ellipsoids and capillaries were, however, unaffected.

All fish injected with either bacteria or ECPs showed dilatation of kidney sinusoids. In the haematopoietic tissue there was a depletion of leucocytes (granulocytes) and erythrocytes, this decrease being clearly evident $3 \mathrm{~d}$ after injection. The spleen of both groups of fish, however, was characterized by a marked increase in the number of granulocytes and immature leucocytes and erythrocytes as well as by the presence of scattered eosinophilic granular cells.

\section{Liver}

Bacteria were seen in the liver at 1 to $2 \mathrm{~d}$ postinjection and were observed in macrophages located in the sinusoids. In later stages of infection, bacteria appeared either inside sub-endothelial macrophages (Fig. 9), or free in the space of Disse, where they formed small colonies without apparent damage to the sinusoidal endothelium, and in some hepatocytes. Invaded hepatocytes showed different levels of injury, depending on the numbers of bacteria they contained. In early stages, hepatocytes showed margination of nuclear chromatin and autolysosomes of varying size in the cytoplasm. Vesiculation of the endoplasmic reticulum was also frequently observed (Fig. 10). In later stages, hepatocytes were necrotic and bacteria formed small colonies. Hepatocytes surrounding the colonies usually had a normal appearance.

Livers of fish injected with ECPs showed consistent alterations, being especially marked $3 \mathrm{~d}$ after injection. Structural analysis revealed multiple foci of necrotic hepatocytes showing large intracytoplasmic granules and vacuoles, and some with pyknosis and karyolysis.

Figs. 1 to 6. Sparus aurata infected with Pasteurella piscicida. Fig. 1. 1 h post-injection (p.i.). Transmission electron micrograph showing a peritoneal granulocyte containing 2 phagocytosed bacteria. Note the altered bacterium (arrow) inside a phagocytic vacuole and the marked degranulation (arrowheads). An apparently intact bacterium (B) is also observed. $\times 10500$. Fig. $2.4 \mathrm{~d}$ p.i. (a) Peritoneal macrophages (M) containing large numbers of phagocytosed bacteria. Granulocyte (G). (b) Peritoneal granulocyte showing phagocytosed bacteria (arrow). M-G, $\times 1250$. Fig. 3. Kidney, 6 h p.i. Transmission electron micrograph showing a macrophage containing phagocytosed apparently intact bacteria. A bacterium (arrowheads), which appeared to be dividing, is also noted. Nucleus (N) $\times 9800$. Figs 4,5 \& 6 . Kidney of fish injected with bacteria (4 d p.i.). Fig. 4 . Transmission electron micrograph showing 2 macrophages containing phagocytosed bacteria (B). Although macrophages have a different electron density, the plasma membrane is well preserved (arrowheads). Note also, extracellular bacteria (arrow) $\times 5200$. Fig. 5 . Transmission electron micrograph showing an altered macrophage containing many phagocytosed bacteria. The cell shows disruption of the phagocytic vacuole membrane (arrow), condensation of the cytoplasm, and vesiculation of the endoplasmic reticulum (arrowheads). Phagolysosome (star). $\times 6200$. Fig. 6. Bacteria were observed inside macrophages (arrows) or forming a colony (B). Cells surrounding the colony were apparently normal. Toluidine blue, $\times 1200$

Fig. 7. Sparus aurata. Kidney of fish injected with extracellular products (ECPs) ( $3 \mathrm{~d}$ p.i.). Large numbers of macrophages (M) containing abundant cell debris are seen within the haematopoietic tissue. Sinusoid (S). Toluidine blue, $\times 500$ 


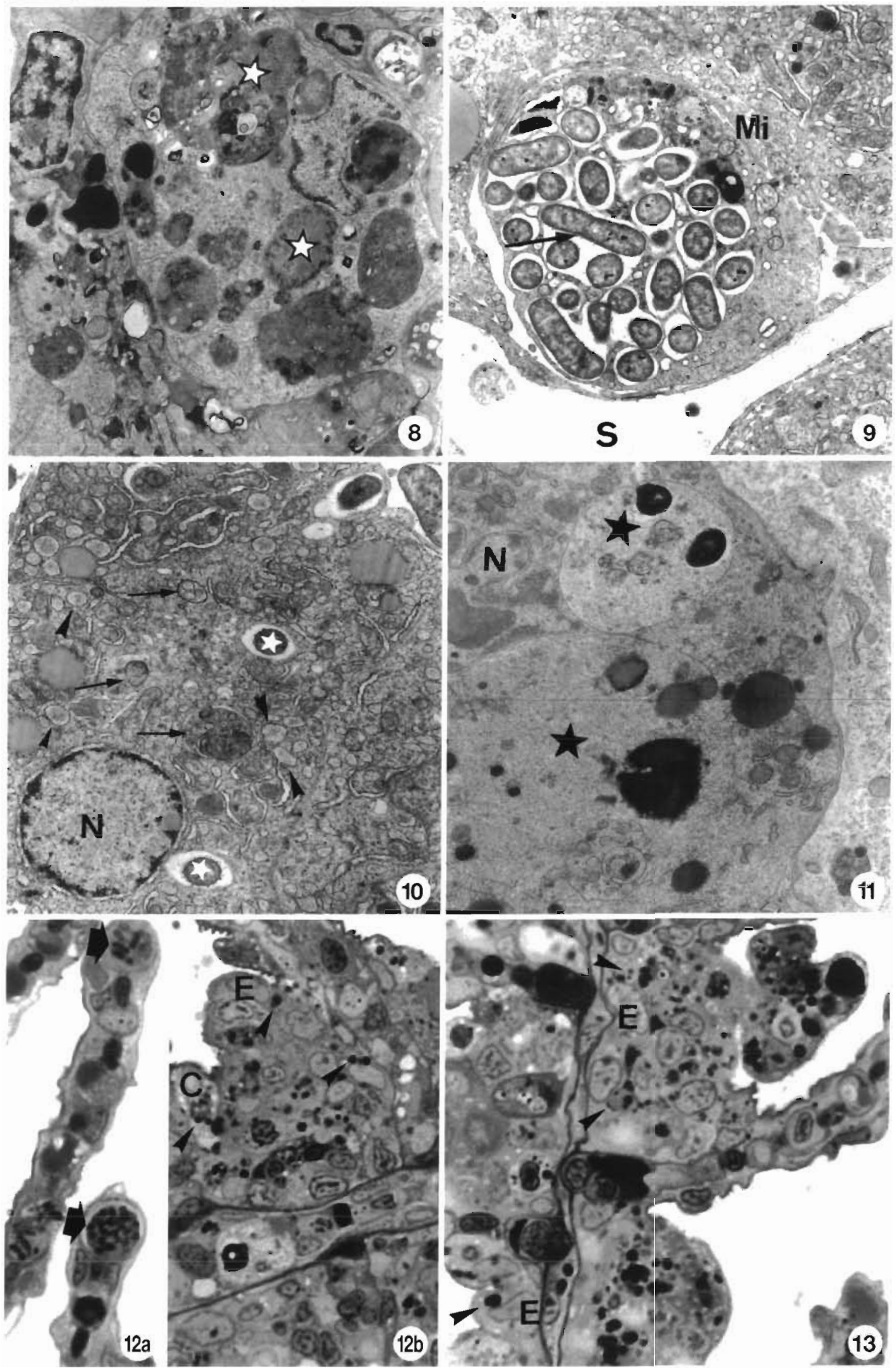


Figs. 8 to 13. Sparus aurata. Fig. 8. Transmission electron micrograph of the spleen of fish injected with ECPs (3 d p.i.). Hypertrophied macrophage located in the ellipsoidal wall containing numerous phagolysosomes (stars). $\times 6850$. Figs. $9 \& 10$. Transmission electron micrographs of the liver of fish injected with bacteria ( $4 \mathrm{~d}$ p.i.). Fig. 9. Sub-endothelial macrophage containing a large number of phagocytosed bacteria, some of them dividing (arrow). Microvilli (Mi). Sinusoid (S). x6000. Fig. 10. Hepatocyte invaded by bacteria (stars). Note chromatin margination of the nucleus ( $N$ ), the presence of lysosomes (arrows) containing cytoplasmic organelles, interpreted as early autolysosomes, and vesiculation and dilatation of the rough endoplasmic reticulum (arrowheads) $\times 6750$. Fig. 11 Liver of fish injected with ECPs (2 d p.i.). Transmission electron micrograph of an altered hepatocyte showing 2 enlarged lysosomes (stars) as well as folding of the nuclear membrane. Nucleus (N). $\times 9450$. Fig. 12. Gills of fish injected with bacteria (4 d p.i.). (a) Lamellae showing macrophages containing many bacteria (arrows) in the capillary lumen. (b) Note the presence of dark granules (arrowheads) in the cytoplasm of the epithelial (E) and chloride (C) cells in the primary gill lamellae. Toluidine blue, $\times 1100$. Fig. 13. Gills of fish injected with ECPs ( 3 d p.i.) showing abundant dark granules (arrowheads) in the cytoplasm of epithelial cells (E). Toluidine blue, $\times 1200$

At the subcellular level, most hepatocytes had chromatin margination as well as large autophagic vacuoles and residual bodies in the cytoplasm (Fig. 11). Reduction of the size of hepatocyte microvilli or, sometimes, their loss was observed, and the space of Disse was often collapsed.

\section{Gills}

Although there were differences between individuals, fish injected with either bacteria or ECPs exhibited changes in the gills. These changes were usually evident after $1 \mathrm{~d}$ in fish injected with ECPs and after $3 \mathrm{~d}$ in
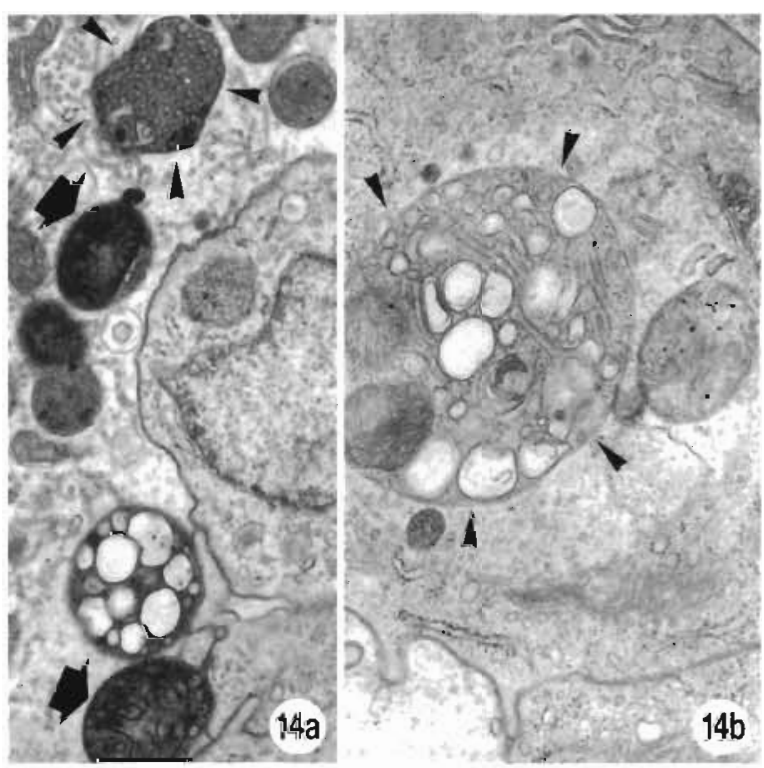

Fig. 14. Sparus aurata infected with Pasteurella piscicida. Transmission electron micrograph of the gills of fish injected with bacteria (4 d p.i.). (a) Chloride cell showing autolysosomes containing cytoplasmic membranous tubules (arrowheads) or disintegrating mitochondria (arrows). $\times 9300$. (b) Epithelial cell showing a large autolysosome (arrowheads) containing mitochondria and other cytoplasmic organelles. $\times 17500$ fish injected with bacteria. In both cases, a progressive increase in the number of macrophages and granulocytes was found in blood spaces (Fig. 12a) and between the epithelial cells of the lamellae, filament, and gill arch. Epithelial and chloride cells suffered degenerative changes, being more severe in fish injected with ECP. Using light microscopy, both types of cells had dark intracytoplasmic granules of different size (Figs. 12b \& 13). Using electron microscopy, we observed that these granules were dense osmiophilic mitochondria or autolysosomes of different size (mainly containing mitochondria and endoplasmic reticulum) (Fig. 14a, b).

At $6 \mathrm{~h}$ after ECPs injection, degranulation of eosinophilic granular cells of gill filaments and arches was observed. After $1 \mathrm{~d}$, these cells were frequently degranulated and with an irregular morphology (Fig. 15).

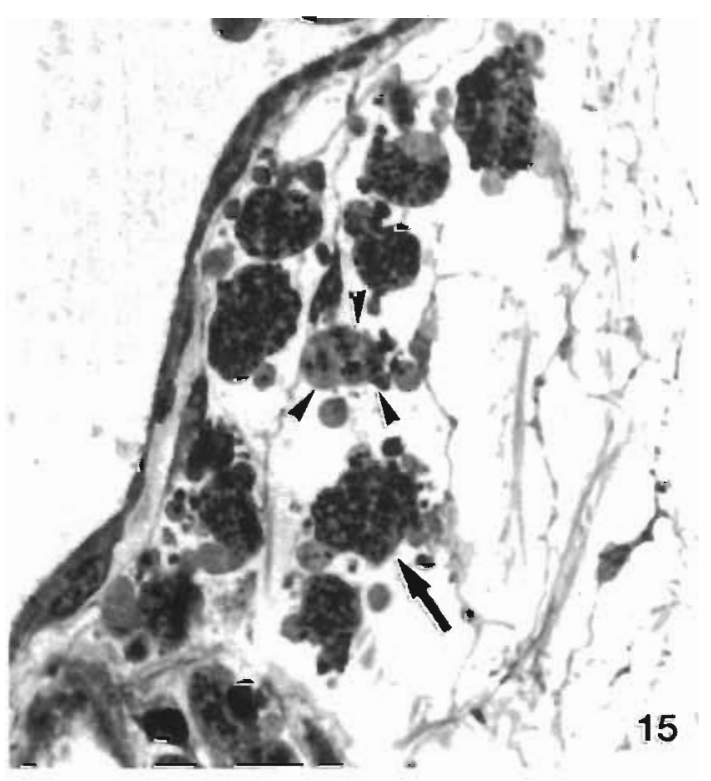

Fig. 15. Sparus aurata. Gill arch of a fish injected with ECPs (1 d p.i.). Eosinophilic granular cells located between the connective tissue have an irregular morphology (arrow) and some of them seem to be degranulated (arrowheads). Toluidine blue, $\times 1000$ 
Eosinophilic granular cells containing granules of varying size and macrophages containing abundant phagocytosed cell debris were also observed in these areas at $3 \mathrm{~d}$ post-injection.

Skin and muscle

Bacteria multiplied extensively in the muscle adjacent to the site of injection, and necrosis of muscle fibres occurred at the injection sites. An intense inflammatory reaction was observed at this level. Alterations caused by the ECPs in the muscle adjacent to the site of injection were mild and only leucocyte infiltration and vasodilatation were observed. Muscle fibres were, however, usually unaffected. No lesions were observed in the skin in any case.

Heart

Both bacteria and ECPs induced a marked vacuolation of endocardium although the changes were much more severe in fish injected with ECPs. Myocardium was apparently unaffected (Fig. 16).

\section{Intestine}

Fish injected with ECPs had abundant macrophages containing large amounts of cell debris, localized along

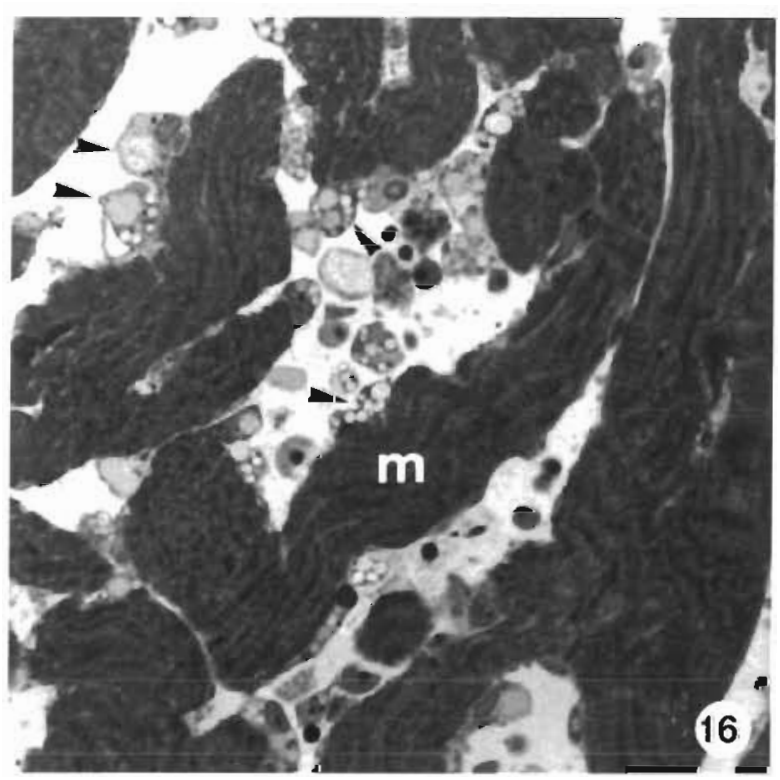

Fig. 16. Sparus aurata. Ventricle of a fish injected with ECPs (2 d p.i.). Note a marked vacuolation of endocardial cells (arrowheads). Cardiac muscle fibre $(\mathrm{m})$. Toluidine blue, $\times 600$ the lamina propria and in the submucosa. The number of these macrophages increased with time. Both bacteria and ECPs induced degranulation and mobilization of the eosinophilic granular cells to the muscle layers and to the serous membrane.

\section{DISCUSSION}

This sequential pathological study suggests that macrophages may be involved in disseminating the bacterium throughout the fish. This pathogenesis is consistent with previous observations in fish infected with Pasteurella piscicida (Kubota et al. 1970a, b, 1972 Nelson et al. 1989). According to Nelson et al. (1989), $P$. piscicida might be viable inside macrophages of yellowtail Seriola quinqueradiata. Results of the present research indicate that bacteria were phagocytosed by macrophages and that phagocytosed bacteria appeared to be morphologically unaltered or even in the process of proliferating within macrophages. Although little is known about the interaction of $P$. piscicida with fish phagocytes, it seems likely that the bacterium survive inside macrophages, perhaps because of resistance to macrophage killing activity or to an absence of macrophage activation. A more detailed study of the relationship of $P$. piscicida with fish macrophages must be carried out.

The inflammatory responses associated with the injection of Pasteurella piscicida and its ECPs were similar. Injected fish showed lymphopenia and an increase in the number of circulating granulocytes and monocytes as well as the presence of immature circulating granulocytes. Accumulation of granulocytes, monocytes and eosinophilic granular cells in the peritoneal fluid as well as vasodilatation and oedema of the muscle adjacent to the site of the injection were noted. These events agree with those found in acute inflammatory responses in fish (Weinreb 1958, Finn \& Nielson 1971) and in mammals (Warren et al. 1990). Study of the phagocytic activity of peritoneal exudate cells showed that gilthead seabream granulocytes phagocytosed and killed $P$. piscicida, suggesting that they play an important role in the early events after injection. However, the low number of phagocytosed bacteria observed in these granulocytes in the later stages of infection, in comparison with macrophages, suggests that their role in bacterial dissemination is minor and probably related to the limited life-span of granulocytes. The presence of necrotic granulocytes in the peritoneal cavity at $6 \mathrm{~h}$ after injection may be a result of the interaction of the cell with the microorganisms, due to the intense degranulation experienced by these cells after phagocytosis of the bacterium or to the accumulation of toxic substances in the peritoneal cavity. 
The mobilization and changes in the morphology of the eosinophilic granular cells of the gill and intestine of gilthead seabream in response to the injection of $P$. piscicida or its ECPs were similar to the effects observed in the eosinophilic granular cells of rainbow trout injected with Aeromonas salmonicida and Vibrio anguillarum ECPs (Lamas et al. 1991, Powell et al. 1993). These changes suggest that eosinophilic granular cells are involved in inflammatory responses in fish.

The lesions observed in Sparus aurata associated with Pasteurella piscicida may be a consequence of the invasion 'strategy' of the bacterium. In advanced stages of infection, aggregates of degenerate macrophages full of apparently intact bacteria and bacterial colonies of varying size were observed in several organs, suggesting that these colonies may be a result of the destruction of microorganism-laden macrophages. However, the histopathological changes surrounding the colonies were usually mild or undetectable, suggesting that the toxins released by the bacterium are not very destructive. These changes were consistent with those caused by the ECPs which also showed a tissue-destructive capacity that was very poor in comparison to the ECPs of other fish pathogens such as Aeromonas salmonicida (Ellis et al. 1981) or Vibrio anguillarum (Lamas 1992). The absence of lesions in the muscle adjacent to the site of ECP injection or in the spleen ellipsoids following ECP injection may be related to the low proteolytic activity shown in vitro by the ECPs of the strain used in this study (Magariños et al. 1992) and may explain the low tissue-destructive capacity of the bacterium.

Fish injected with ECPs had a notable decrease in the number of circulating erythrocytes. The presence of numerous degenerate erythrocytes in the blood or phagocytosed by macrophages corroborates the presence of the haemolytic activity demonstrated in vitro (Magariños et al. 1992). However, the reduction in the number of circulating erythrocytes in fish injected with Pasteurella piscicida was not significant. This mild haemolysis due to the bacteria in vivo may reflect the fact that the bacteria spend most of the time inside macrophages during the development of the infection; it is only in the later stages of the infection, after destroying the macrophages, that they occur as free colonies. As a consequence, the release of haemolysins to the blood would be restricted to the last part of the infection. These results indicate that haemolysins may not be a major factor in the lethality of fish pasteurellosis.

The toxicity of the bacterium for hepatocytes and endothelial cells appeared to be restricted to the regions where the bacterium proliferated, although the epithelial and chloride cells of the gill lamellae showed acute degenerative changes even when they were not invaded by the bacterium. These changes may be due to the toxic activities of its ECPs. The alterations caused by the ECPs to these organs were especially evident $3 \mathrm{~d}$ after injection and were more severe than those caused by bacteria. This difference in toxicity may be explained by the bacterium requiring time to produce the ECPs and the ECPs needing time to cause lesions. The severe lesions caused by the ECPs to these organs may be related to their physiological function. The liver is involved in detoxification and, in consequence, is especially liable to suffer injuries from toxins that it accumulates. The role of the epithelial and chloride cells in respiration and osmoregulation may also make them sensitive to the toxins circulating in the blood

The cause of fish death by Pasteurella piscicida infection is still unknown. Previous reports have suggested that fish may die by bacterial embolism or by suffocation due to macrophage infiltration in the gill lamellae (Kubota et al. 1970a, Nelson et al. 1989). The toxic activities of the ECPs demonstrated in the present study, especially in certain critical organs, suggest that the toxins play a role in the pathogenesis of the disease.

Acknowledgements. This study was supported by grants (MAR 91-1133-C02-01 and AGF94-1360-C03-01) from the Comisión Interministerial de Ciencia y Tecnología (CICYT). B.M. acknowledges the Xunta de Galicia for research fellowship. The authors thank Prof. Ramón Anadón for the critical reading of the manuscript and J. M. Leboreiro (Granja Cultivo Integral de Rodaballo, Quilmas, Carnota, Spain) for the supply of fish needed for the various experiments.

\section{L.ITERATURE CITED}

Bradford MM (1976) A rapid and sensitive method for the quantitation of microgram quantities of protein utilizing the principle of protein-dye binding. Analyt Biochem 72 : $248-254$

Ellis AE, Hastings TS, Munro LS (1981) The role of Aeromonas salmonicida extracellular products in the pathology of furunculosis. J Fish Dis 4:41-51

Finn JP, Nielson NO (1971) The inflammatory response of rainbow trout. J Fish Biol 3:463-478

Hawke JP, Plakas SM, Minton RV, McPherson RM, Snider TG, Guarino AM (1987) Fish pasteurellosis of cultured striped bass, Morone saxatilis, in coastal Alabama. Aquaculture 65:193-204

Kitao T (1993) Pasteurellosis. In: Inglis V, Roberts RJ, Bromage NR (eds) Bacterial diseases of fish. Blackwell Scientific Publ, Oxford, p 159-165

Kubota S, Kimura M, Egusa S (1970a) Studies of a bacterial tuberculoidosis of the yellowtail. I. Symptomatology and histopathology. Fish Pathol 4:111-118

Kubota S, Kimura M, Egusa S (1970b) Studies of a bacterial tuberculoidosis of the yellowtail. II. Mechanism of nodule formation. Fish Pathol 5:31-34

Kubota S, Kimura M, Egusa S (1972) Studies of a bacterial tuberculoidosis of the yellowtail. III. Findings on nodules and bacterial colonies in tissues. Fish Pathol 6:69-72 
Kusuda R, Salati F (1993) Major bacterial diseases affecting mariculture in Japan. In: Inglis V, Roberts RJ, Bromage NR (eds) Bactenal diseases of fish. Blackwell Scientific Publ, Oxford, p 69-85

Lamas J (1992) Alteraciones experimentales causadas por Vibrio anguillarum y sus productos extracelulares en trucha arcoiris. Aspectos citológicos e histopatológicos $\mathrm{PhD}$ thesis, University of Santiago de Compostela

Lamas J, Bruno DW, Santos Y, Anadón R, Ellis AE (1991) Eosinophilic granular cells response to intraperitoneal injection with Vibrio anguillarum and its extracellular products in rainbow trout, Oncorhynchus mykiss. Fish Shellfish Immunol 1:187-194

Magariños B, Santos Y, Romalde JL, Barja JL, Toranzo AE (1992) Pathogenic activities of live cells and extracellular products of the fish pathogen Pasteurella piscicida. J gen Microbiol 138:2491-2498

Nelson JS, Kawahara E, Kawai K, Kusuda R (1989) Macrophage infiltration in pseudotuberculosis of yellowtail, Seriola quinqueradiata. Bull mar Sci Fish, Kochi Univ $11: 17-22$

Powell MD, Briand HA, Wright GM, Burka JF (1993) Rainbow trout (Oncorhynchus mykiss Walbaum) intestinal eosinophilic granule cells (EGC) response to Aeromonas salmonicida and Vibrio anguillarum extracellular products.

Responsible Subject Editor: T Evelyn, Nanaimo, B.C., Canada
Fish Shellfish Immunol 3:279-289

Thune RL, Stanley LA, Cooper RK (1993) Pathogenesis of gram-negative bacterial infections in warmwater fish. In: Faisal M, Hetrick FM (eds) Annual review of fish diseases Pergamon Press, New York, p 5-36

Toranzo AE, Barreiro S, Casal JF, Figueras A, Magariños B, Barja JL (1991) Pasteurellosis in cultured gilthead seabream, Sparus aurata: first report in Spain. Aquaculture 99:1-15

Tung MC, Tsai SS, Ho LF, Huang ST, Chen SC (1985) An acute septicemic infection of Pasteurella organism in pond-cultured Formosa snake-head fish (Channa maculata Lacepede) in Taiwan. Fish Pathol 25:143-148

Warren JS, Ward PA, Johnson KJ (1990) The inflammatory response. In: Williams WJ, Beutler E, Erslev AJ, Lichtman MA (eds) Hematology, 4th edn. McGraw-Hill, Inc, New York, p 63-70

Weinreb EL (1958) Studies on the histology and histopathology of the rainbow trout, Salmo gairdneri irideus. l. Hematology: under normal and experimental conditions of inflammation. Zoologica 46:145-152

Wolke RE (1975) Pathology of bacterial and fungal diseases affecting fish. In: Rubelin W, Migaki G (eds) The pathology of fishes. University of Wisconsin Press, Madison, p $33-116$

Manuscript first received: March 9, 1994

Revised version accepted: November 6, 1994 